\title{
An Economic Analysis of
} China's Domestic Crude Oil Supply Policies

Bertrand Rioux, Philipp Galkin and Kang Wu 


\section{About KAPSARC}

The King Abdullah Petroleum Studies and Research Center (KAPSARC) is a non-profit global institution dedicated to independent research into energy economics, policy, technology and the environment across all types of energy. KAPSARC's mandate is to advance the understanding of energy challenges and opportunities facing the world today and tomorrow, through unbiased, independent, and high-caliber research for the benefit of society. KAPSARC is located in Riyadh, Saudi Arabia.

\section{Legal Notice}

(C) Copyright 2019 King Abdullah Petroleum Studies and Research Center (KAPSARC). No portion of this document may be reproduced or utilized without the proper attribution to KAPSARC. 


\section{Key Points}

hina's domestic oil production has lagged the very rapid growth in domestic oil consumption observed since the beginning of the $21^{\text {st }}$ century, leading to a large, and growing, reliance on imports to meet demand. China's current market structure and regulatory environment, among other factors, impede further development of the country's oil industry, despite a number of policies aimed at protecting domestic producers.

Using a short-run equilibrium model of China's oil and gas supply industry, calibrated to 2016 data, we assess the impact of market access barriers on China's domestic production. We find that:

Lifting all import constraints could have increased China's import demand by around 0.29 million barrels per day (MMbbl/d) in 2016.

Opening China's market to cheaper oil imports in 2016 could have saved approximately $\$ 2.8$ billion, equivalent to $1.7 \%$ of the country's oil supply costs, primarily due to import substitution for 17.8 million metric tonnes (MMmt), or equivalent to 0.29 million barrels per day (MMbbl/day), about $9 \%$ of domestic production that operates uncompetitively (see Figure 2).

Liberalization of the import regime improves the efficiency of oil logistics through better utilization of the country's existing pipeline network, leading to a $\$ 600$ million decline in overall oil transportation costs.

Figure 2. China's supply curve for domestic production, before transportation, in the 2016 reference and open market scenarios.

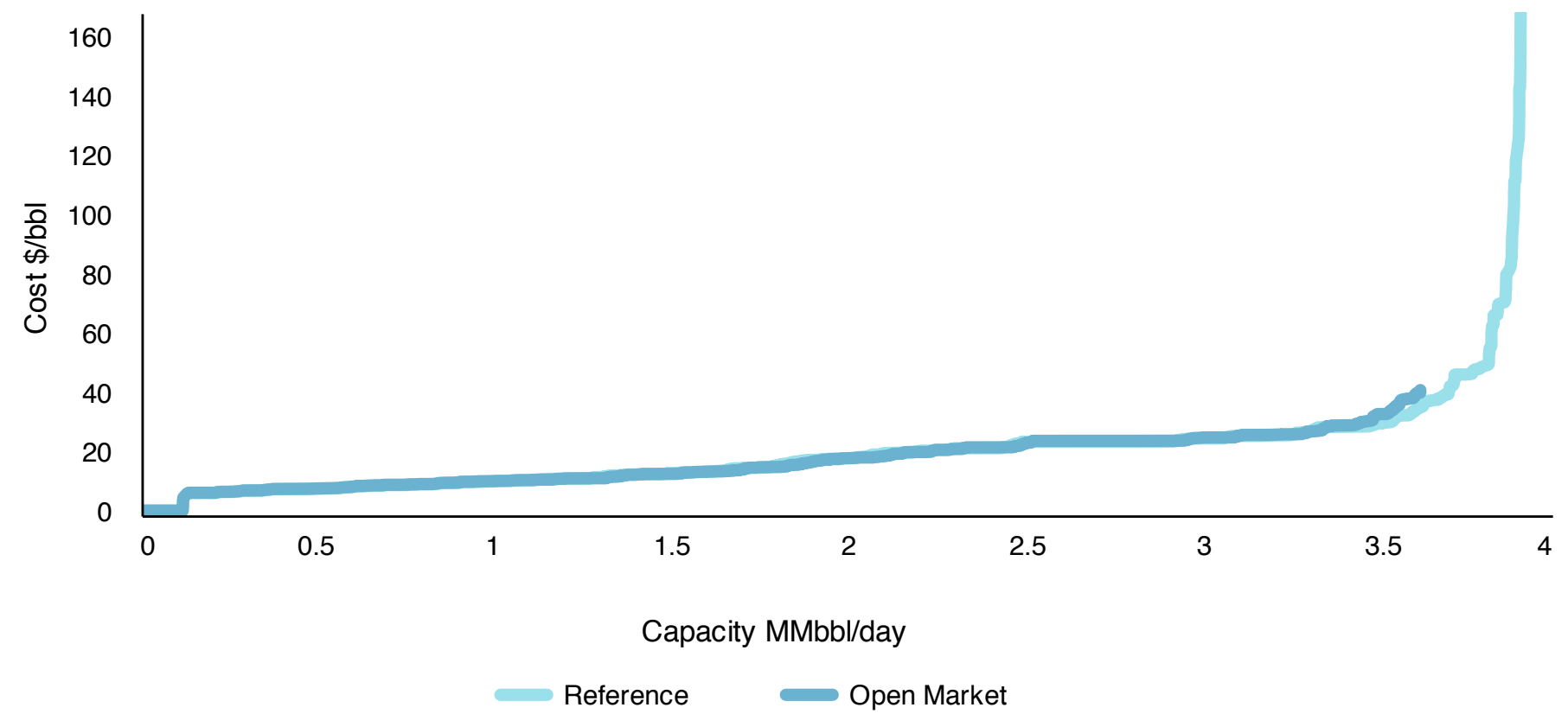

Sources: IHS Vantage, KAPSARC research. 


\section{Key Points}

The level of uneconomic oil production in China is highly sensitive to the international oil price. At $\$ 50$ per barrel (bbl), only $9 \mathrm{MMmt}$ of domestic supplies are found to be uneconomic, about half the level reported at 2016 prices. Despite the big reduction in output, producing these uneconomic oil resources would account for about $\$ 2.5$ billion of additional costs. This number drops to $6.6 \mathrm{MMmt}$ under September 2018 prices (close to an average $\$ 80 / \mathrm{bbl}$ ), at a cost of $\$ 1.1$ billion.

Rising import prices since mid-2017 may provide a window of opportunity for Chinese policymakers to proceed with further deregulating the domestic oil sector, as the potential short-term impact on domestic producers will be less pronounced than when imported crude is cheap. 


\section{Summary}

C hina's demand for crude oil has grown significantly since 2000. Despite the country's substantial oil resources, production by China's national oil companies has lagged demand: in 2016 imports accounted for around $70 \%$ of total supplies. The projections indicate continued strong demand for oil in the short and medium term, which will further shift the country's oil supply balance toward imports.

The Chinese government has been pursuing several strategies to secure its oil supply base, including diversifying the sources of international supplies; securing controlling stakes in foreign exploration and production assets, investing in pipeline and storage (midstream) infrastructure projects; and increasing its strategic petroleum reserve at times of lower oil prices, particularly during 2015-2017.

Policies targeting higher domestic oil output, such as intensifying oil exploration in China, developing the country's vast unconventional hydrocarbon reserves and building a more extensive national pipeline network have not, however, resulted in any significant oil output growth to date. Aging conventional production assets, rising marginal production costs and the complex geology of China's unconventional oil and gas resources have all contributed to a failure to meet the domestic oil supply challenge.

In addition to physical and geological constraints, market structure issues and regulatory barriers have also come into play. The dominance of three state-owned oil production companies and the slow pace of reform have impeded the development of China's domestic upstream sector. Direct and indirect protectionist policies that prioritize domestic producers, which include import licensing restrictions, limited third-party access to pipeline and port infrastructure and other market access barriers, reduce real competition from imports and distort the domestic oil market, especially when oil prices are perceived to be low. Specific barriers and their impacts can be difficult to distinguish due to variance in interpretation and actual enforcement of relevant policies. The approach used in this study focuses on the cumulative effect of such restrictions.

In an effort to measure the scale of the economic distortions caused by China's protectionist policies, we have developed a short-run equilibrium model of China's wholesale oil and gas market at the provincial scale. The model is calibrated to 2016 conditions, the year when oil import prices reached their lowest level since 2004. We construct counterfactual scenarios to provide an alternative view of the market, assuming the Chinese government lifts its protectionist policies. Oil production levels, spare capacity, logistical flows, total supply costs and other model outputs are presented to measure the potential impact of removing policies that restrict crude imports, and prioritize local suppliers.

We estimate that lifting oil import license constraints and other policies protecting domestic oil producers could have reduced China's supply costs by roughly $\$ 3$ billion in 2016. The majority of these savings come from a $27 \%$ reduction ( $\$ 7.9$ billion) in oil production costs, accounting for 17.8 million metric tonnes (MMmt) of domestic output replaced by imports. Metric tonnes $(\mathrm{mt})$ of oil are the standard unit of measurement used in official Chinese statistics. The average gravity of the displaced production gives a conversion rate of is 6 barrels $/ \mathrm{mt}$, or about 0.29 million barrels per day (MMbbl/d) of equivalent imports.

Our analysis shows a steep incline in the last $10 \%$ of China's domestic supply curve, accounted for by a number of mature fields with higher production costs, including several with declining output. In addition, many of these fields are located in 
remote areas with limited access to infrastructure compared to coastal import terminals, which are closer to China's main energy consumption centers. As a result, cheaper pipeline shipments using existing spare capacity can replace long haul tanker shipments by rail or truck, in theory reducing transportation costs by about $\$ 0.6$ billion in 2016 .

These findings indicate that China's current protectionist policies interfere with the regional and national supply-demand equilibrium and impede the optimal allocation of capital in the upstream oil and midstream transportation sectors. This leads to increased system costs and undermines the longterm competitiveness of the industry. The estimated potential effects of deregulating China's oil industry also have significant implications for the global oil market, given that the proportion of imports in China's oil balance may turn out to be higher than expected as a result of removing the restrictions put in place by Chinese policymakers.
The impacts of protectionist policies were found to be less pronounced under high import prices. The level of unused production capacity falls rapidly, to only $9 \mathrm{MMmt}$, when oil imports average $\$ 50 / \mathrm{bbl}$, and to $6.6 \mathrm{MMmt}$ at $\$ 80 / \mathrm{bbl}$. At the time of writing (December 2018), oil prices had been fluctuating within this range, dropping to levels observed at the end of 2016 after a period of sustained growth, which started in the second half of 2017. These big price swings complicate the assessment of how reform initiatives would impact domestic suppliers in the short run. However, even at the oil import prices recorded at the time of writing, which were higher than the 2016 average, the short-term impact on domestic producers will be less pronounced than under the 2016 market conditions. This provides a window of opportunity for Chinese policymakers to deregulate the country's upstream oil sector further and remove protectionist policies in order to support the sustainable long-term development of the country's domestic oil industry. 


\section{China's Crude Oil Market}

hina's demand for crude oil has more than doubled since 2000 , driven by rapid economic growth, industrialization and increasing exports of refined petroleum products, mainly to other Asian markets. The growth in demand for crude significantly outpaced domestic supply, which rose $23 \%$ over the same period (CEIC 2018). As shown in Figure 1, the gap in the crude oil balance has been filled by an increasing reliance on imports that approached $70 \%$ of the country's demand in 2016 (ITC 2018). In conjunction with the displacement of a large percentage of imports by the United States (U.S.), prompted by the boom in U.S. shale oil production, China overtook the U.S. as the world's biggest crude oil importer in 2017 (EIA 2018a).
The aforementioned shifts in China's crude oil supply balance have raised energy security concerns among analysts and the country's policymakers. The policy response has primarily focused on securing oil imports from a diversified range of suppliers and through acquiring control over foreign oil resources via investments in upstream assets and midstream infrastructure in other countries. However, Beijing's efforts to stimulate production at home through intensifying exploration, developing China's extensive unconventional hydrocarbon reserves and speeding up the construction of inter-regional pipeline networks, have not yet resulted in any significant output increase. Conversely, China's domestic oil production has been in falling since 2015 (EIA

Figure 1. China's crude oil demand, domestic production and share of imports.

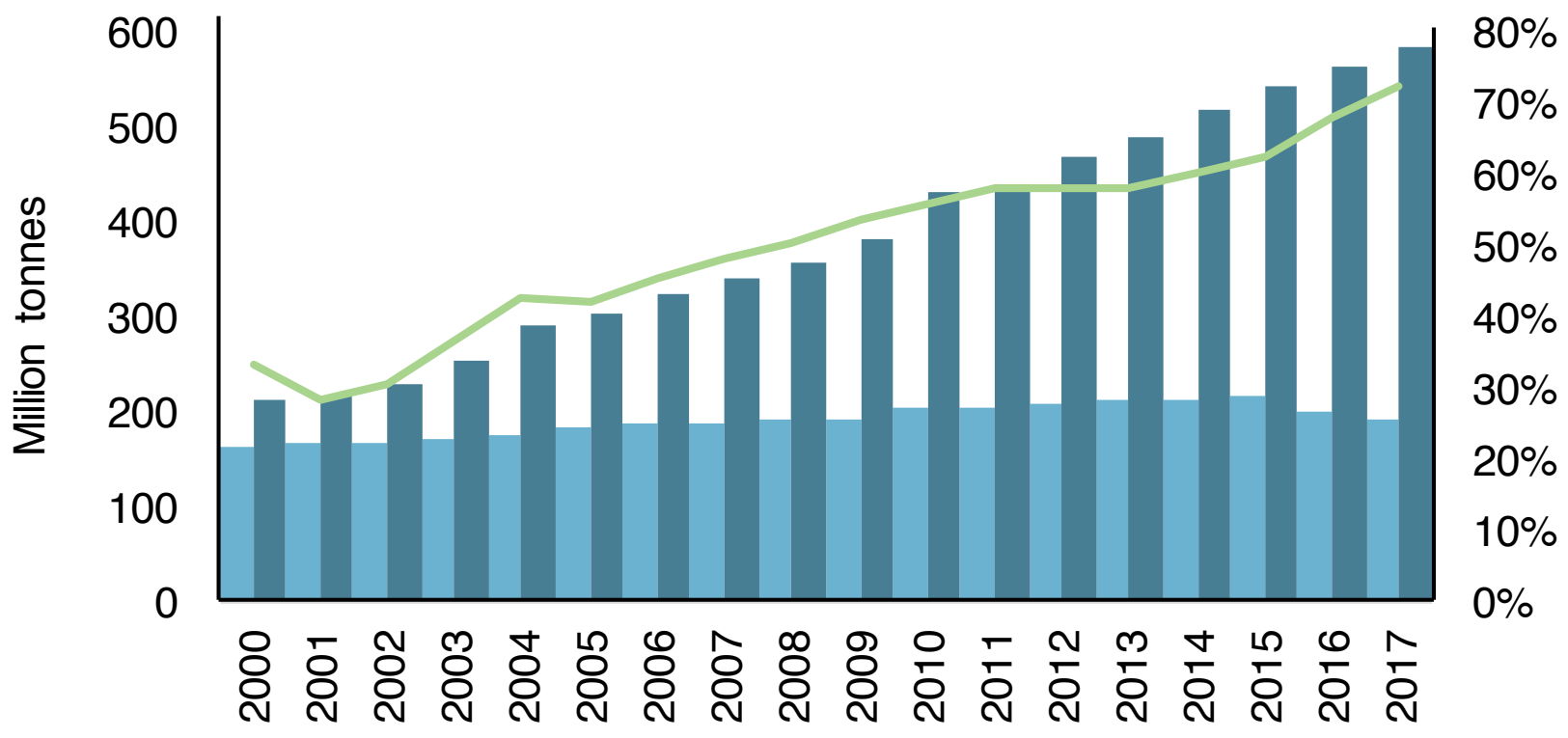

Production Consumption - Imports as \% of consumption (right axis) 
2018a). Analysts cite aging conventional production assets, the need to develop technology to address challenging geological conditions, limited access to water, high market concentration levels, and the insufficient pace of reform as some of the major problems facing the Chinese upstream sector.

According to the U.S. Energy Information Administration (EIA), China holds the 13th largest proven conventional oil reserves in the world, at 25.62 billion bbl (EIA 2018b). China's unconventional proven oil reserves, including heavy and extraheavy oil, oil sands, tight oil and kerogen oil, are also among the world's largest, adding another 13 billion bbl (Wang et al. 2015).

China's conventional onshore and shallow water oil production mainly comes from a few large mature fields, notably Daqing, Shengli and Liaohe. Output from these fields in 2016 dropped by $9.5 \%$ compared to the previous year (Oilprice.com 2017).

China's unconventional oil production is also unlikely to increase significantly in the near future because of geological, technological and economic constraints. Chinese shale oil resources tend to be heavier than those in the U.S., being waxier and containing a smaller share of condensates (Gordon et al. 2014). In addition, the shale oil reserves in China's major basins, e.g., Tarim and Junggar, lie deep underground in hard geological formations, making their extraction process capital-, energy- and technology-intensive. Also, the remote location of these two basins - in the country's western provinces, a long distance from major demand centers and existing infrastructure - further undermines the economics of their development.

In addition, the current structure of China's oil market and regulatory environment are not conducive to boosting domestic oil production.
Market participants are either unable or unwilling to accumulate sufficient capital to increase investments in domestic exploration and production. China's upstream sector is highly concentrated and is dominated by the country's three big national oil companies (NOCs): China National Petroleum Corporation (CNPC), China Petroleum \& Chemical Corporation (Sinopec), and China National Offshore Oil Corporation (CNOOC), the last of which is responsible for offshore development. CNPC accounts for about $54 \%$ of China's domestic oil production, most of the remaining domestic onshore fields (19\%) are operated by Sinopec, CNOOC's production accounts for $20 \%$, while private companies account for the remaining 7\% (IHS Vantage 2018). Foreign oil companies' participation in Chinese oil production is restricted to production sharing contracts with designated NOCs.

China's midstream is also dominated by the three NOCs. CNPC owns or operates more than $70 \%$ of the country's oil pipelines, while Sinopec has access to more crude oil import terminals than other market participants (IHS EDIN 2018). Although privatelyowned companies can engage in crude oil storage, trading and importation, their market access is effectively restricted by the need to obtain business permits and import licenses from the Ministry of Commerce, as well as by the import quotas and other administrative barriers imposed on non-stateowned enterprises.

Despite their market dominance, the NOCs' profits and cash flows are negatively affected by certain sectoral regulations that apply in China, such as state-controlled pricing mechanisms for refined petroleum products and for some segments of the natural gas market. While China's domestic crude oil prices have been in relative alignment with the global market since the late 1990s, the domestic pricing mechanisms for petroleum products are still 
not entirely market-based. Refined product prices shift based on a 10-working day moving average and are subject to ad hoc interventions from the government. The management of retail prices for gasoline and diesel is still in the hands of the regulators.

These regulatory and structural hurdles will likely factor into preventing China from reaching its ambitious oil and energy policy targets. Under Beijing's 13th Five-Year Plan (FYP), China is scheduled to produce $200 \mathrm{MMmt}$ of crude oil by 2020 - requiring a reversal of the current downward output trend. The FYP also foresees China adding 5 billion mt of proven oil reserves, as well as making significant progress in the exploration and development of unconventional oil resources (NDRC 2016). Beijing has also set a target of more than $80 \%$ energy self-sufficiency by 2020 (NEA 2016).

Strong oil demand projections will further shift the country's supply balance toward imports. The $13^{\text {th }}$
FYP for Petroleum Development forecasted overall oil consumption of $590 \mathrm{MMmt}$ by 2020 (NDRC 2016). However, several analysts and industry participants have predicted higher numbers: for example, CNPC expected domestic crude oil demand to hit $600 \mathrm{MMmt}$ in 2018 (S\&P Global Platts 2018a) and a ceiling of 690 MMmt by 2030 (Reuters 2017). Other factors that will likely contribute to continued oil demand growth include the projected intensified building of China's strategic petroleum reserve, which is targeted to reach $500 \mathrm{MMbbl}$, or the equivalent of 90 days of net imports, by 2020 , and the development of more commercial oil storage facilities (S\&P Global Platts 2018b).

Chinese policymakers remain keen to reform the country's energy sector. Relevant strategic plans emphasize the need to rely more on market drivers, facilitate market access and competition and strengthen the supervision of the relevant stateowned monopolies or oligopolies. The reform plan

\section{Development of the Shanghai Crude Oil Futures contract}

A growing reliance on crude imports and continued integration into foreign trade, investment, finance and international energy governance will require better alignment of China's domestic regulations with its strategic targets, as well as with domestic and global market drivers. The emergence of Singapore-based Chinese trading houses and their dominance on the Dubai Mercantile Exchange (DME), and more recently the launch of crude oil futures contracts on the Shanghai International Energy Exchange (INE) in March 2018 demonstrate efforts by China to strengthen its role in the global oil market. The INE contracts are based on medium sour crude oil similar to Dubai and Oman crude markers. The shortest term INE contract emerged as the third most traded oil futures contract globally in 2018 with a 16\% market share, overtaking the volume for similar contracts traded on the DME (Nikkei 2018). However, the INE contract still tracks the better-known and more liquid Brent and West Texas Intermediate benchmarks and is unlikely to become a regional benchmark for refineries in the near future. So far, the INE crude futures contract is being used primarily by local speculators and has yet to attract major international players (Reuters 2018b). The success of the contract depends not only on the ability to attract a sufficiently large pool of traders and provide the necessary tools to manage price volatility, but also on a predictable and non-adverse policy environment (Till 2014). 
for the oil and gas industry, officially called Several Opinions on Deepening Oil and Gas Sector Reform, which was announced in 2017, outlined measures aimed at deregulating and creating a competitive landscape in the sector (Xinhua 2017). The plan proposed that China's NOCs divest most of their non-core assets, reduce their social commitments and collaborate more with private companies across the oil supply chain, including in the previously restricted domestic exploration and production sectors. The 2017 reform proposal also called for a transition to market-based pricing in both pipeline transportation and sales of refined products, with the government's role reduced to interventions in cases of large price fluctuations (Xinhua 2017).

These reform initiatives, although necessary for the long-term development of the Chinese energy sector in general and for the oil industry in particular, might cause short-term disruptions, as consumers become exposed to marginal costs once all direct or indirect market access barriers are lifted. Such disruptions can have a big impact not only on the domestic oil market but also on global markets, given China's growing role in the global economy and in energy trading.

The 2018-2019 trade dispute between China and the U.S. and the re-imposition of U.S. sanctions on Iran could further complicate China's domestic reform efforts. Concerns that the Chinese government will introduce tariffs on imports of U.S. crude, plus pressure from the U.S. administration to limit oil imports from Iran, led to a rapid decline in imports from Iran and the U.S. by Chinese buyers in the second half of 2018 (Bloomberg 2018; Reuters 2018a). The impact of elevated political tensions on oil markets may call for supplementing domestic sectoral reforms with import diversification and regional collaboration strategies. Qi and Yang (2018) have shown the benefits of the latter approach, using an optimization tool to investigate oil supply risks for East Asian importers.

This study explores the effect of existing government policies, which prioritize domestic supplies from the country's NOCs, on China's oil supply economics and asks:

Can the preservation of domestic oil resources, based on the relative cost of domestic production versus imports, contribute to China's long-term energy supply security?

What are the potential consequences for domestic oil industry players if local consumers are given unrestricted access to global oil markets?

Understanding the potential magnitude of such policy consequences could help the Chinese authorities design policy and also help market participants develop their corporate strategies. 


\section{A Model of China's Oil and Gas Market}

\section{Model Description}

To explore the effects of China's current import regulations, we construct a short-run costs minimization model that represents the annual supply of oil and gas to the Chinese market at the provincial scale. It is built as an extension of the natural gas equilibrium model subject to regional price controls developed by Rioux et al. (2018). The model is structured as a single year, short-run static optimization problem, subject to fixed provincial demand levels, considering only existing production and inter-provincial oil pipeline capacities, with no new investment factored-in. However, annualized capital development costs are included for incremental production from mature fields, required to offset the natural decline in the fields' output.

With respect to modeling oil production, the model design is similar to the petroleum supply chain optimization problem developed by Jiao et al. (2010). Their model covers a range of activities across the supply chain, including refining and petrochemicals, which are not included in our model. However, Jiao does not account for capacity constraints, whereas our model captures existing pipeline network capacities. We use a transshipment model to represent explicit flows by pipeline, rail and truck from origin to destination, including connections between neighboring provinces.

Our pipeline transshipment model is similar to that developed by Yang et al. (2014). Their model applies a higher spatial resolution to identify optimal supply pathways only within China's Eastern pipeline network, whereas our model covers all of the provinces in mainland China. The authors use the tool to investigate inefficiencies in China's existing crude flows. In our study, the transportation model accounts for how transportation costs and constraints can reduce the competitiveness of domestic production. For example, remote producers with limited access to cheaper pipeline transport (versus long haul rail or truck) may be less competitive than imports with access to more developed coastal pipeline networks.

Furthermore, our model tracks the ownership of upstream and midstream assets by China's three big oil producing NOCs, originally used to capture third-party access restrictions on Chinese pipelines. Crude imports by pipeline and by seagoing tanker are permitted. We also set a maximum level on crude imports by seaborne vessels to capture import licensing and other market access constraints. Appendix 1 provides a full description of the oil model.

\section{Model Calibration}

We calibrate our model of China's domestic oil and gas supply to the market conditions observed in 2016. This calendar year was chosen as the most recent 12-month period for which all necessary statistical data was available. In addition, 2016 saw the lowest average international crude oil prices since 2004, providing a good reference year for the potential impact of national policies aimed at prioritizing China's domestic production.

We use metric tonnes $(\mathrm{mt})$ in the calibration and analysis of China's domestic oil production, because this is the standard unit of measurement used in the Chinese government's oil statistics. Conversion to barrels is carried out if the corresponding gravity of the oil is available in the calibration data and tracked by the model. Note that we track crude shipments as metric tonnes, but not density. This is an area where the model could be improved, such as including a regional refining model with constraints on the gravity of crude used as feedstock, or other characteristics (e.g., sulfur content). 
Table 1. China hydrocarbons: supply and demand, by province, in 2016

\begin{tabular}{|c|c|c|c|c|c|c|}
\hline \multicolumn{3}{|c|}{ Supply } & \multicolumn{2}{|l|}{ Demand } & \multicolumn{2}{|c|}{ Supply - Demand } \\
\hline & Oil (MMmt) & Gas (bcm) & Oil (MMmt) & Gas (bcm) & Oil (MMmt) & Gas (bcm) \\
\hline Anhui & 0.02 & 0.00 & 5.39 & 4.31 & -5.37 & -4.31 \\
\hline Beijing & 0.00 & 0.00 & 8.21 & 17.72 & -8.21 & -17.72 \\
\hline Chongqing & 0.01 & 3.19 & 0.00 & 9.87 & 0.01 & -6.68 \\
\hline Fujian & 0.00 & 0.00 & 20.89 & 5.36 & -20.89 & -5.36 \\
\hline Gansu & 0.89 & 0.03 & 13.67 & 2.89 & -12.78 & -2.86 \\
\hline Guangdong & 13.04 & 3.32 & 50.44 & 14.07 & -37.40 & -10.75 \\
\hline Guangxi & 0.04 & 0.00 & 13.4 & 1.39 & -13.36 & -1.39 \\
\hline Guizhou & 0.00 & 0.52 & 0.00 & 1.87 & 0.00 & -1.35 \\
\hline Hainan & 2.65 & 3.52 & 11.19 & 4.54 & -8.54 & -1.02 \\
\hline Hebei & 15.26 & 1.07 & 17.62 & 7.56 & -2.36 & -6.49 \\
\hline Heilongjiang & 35.83 & 2.92 & 22.1 & 4.2 & 13.73 & -1.28 \\
\hline Henan & 2.78 & 0.46 & 7.07 & 10.14 & -4.29 & \begin{tabular}{|l|}
-9.68 \\
\end{tabular} \\
\hline Hubei & 1.03 & 0.12 & 12.4 & 4.54 & -11.37 & -4.42 \\
\hline Hunan & 0.00 & 0.00 & 8.42 & 3.03 & -8.42 & -3.03 \\
\hline Inner Mongolia & 2.32 & 21.19 & 4.20 & 3.67 & -1.88 & 17.52 \\
\hline Jiangsu & 1.44 & 0.24 & 40.92 & 18.77 & -39.48 & -18.53 \\
\hline Jiangxi & 0.00 & 0.00 & 7.26 & 2.06 & -7.26 & -2.06 \\
\hline Jilin & 4.05 & 2.14 & 10.51 & 2.34 & -6.46 & -0.20 \\
\hline Liaoning & 9.57 & 2.01 & 70.57 & 5.44 & -61.00 & -3.43 \\
\hline Ningxia & 0.07 & 0.00 & 5.76 & 2.34 & -5.69 & -2.34 \\
\hline Qinghai & 1.96 & 6.57 & 1.49 & 5.1 & 0.47 & 1.47 \\
\hline Shaanxi & 24.04 & 9.63 & 18.24 & 9.06 & 5.80 & 0.57 \\
\hline Shandong & 41.68 & 1.21 & 102.03 & 10.66 & -60.35 & -9.45 \\
\hline Shanghai & 0.00 & 0.00 & 24.74 & 8.7 & -24.74 & -8.70 \\
\hline Shanxi & 8.53 & 11.44 & 9.15 & 7.65 & -0.62 & 3.79 \\
\hline Sichuan & 0.15 & 23.57 & 9.03 & 18.99 & -8.88 & 4.58 \\
\hline Tianjin & 3.54 & 0.27 & 14.34 & 0.00 & -10.80 & 0.27 \\
\hline Xinjiang & 26.99 & 33.28 & 24.53 & 14.56 & 2.46 & 18.72 \\
\hline Yunnan & 0.00 & 0.00 & 0.00 & 0.85 & 0.00 & -0.85 \\
\hline Zhejiang & 0.11 & 0.45 & 26.67 & 9.31 & -26.56 & -8.86 \\
\hline Total & 196.00 & 127.16 & 560.24 & 210.99 & -364.24 & -83.83 \\
\hline
\end{tabular}

Source: CEIC 2018. 
We calibrate the model to the oil and gas production and demand levels reported in 2016 in China's official provincial balance sheets (CEIC 2018). See Table 1 for a breakdown of provincial supply and demand. The model includes detailed provincial production cost profiles and inter-provincial transportation costs by pipeline and land-based tankers (truck and rail).

Production levels, marginal cost curves, gas-tooil ratios and capital development costs have been calibrated using data compiled from the IHS Vantage upstream database, covering more than 1,200 Chinese oil and gas assets (IHS Vantage 2018). We represent domestic production by ownership, China's three big upstreammidstream NOCs (CNPC, CNOOC and Sinopec) and aggregated independent producers, and by geographic location, i.e., 32 regions including the 30 provinces listed in Table 1, and two offshore nodes, Bozhong in Beihai Bay and Xihu, off the coast of Zhejiang. We include imports by pipeline from Central Asia, Russia and Myanmar, and seaborne tanker imports at every coastal province in eastern and southern China. Oil production and imports are reported in MMmt and gas production in billion cubic meters (bcm). Production costs are reported in U.S. dollars per metric tonne ( $\$ / \mathrm{mt})$ for oil, and in dollars per thousand cubic meters $(\$ / \mathrm{Mcm})$ for gas.

As a short-run optimization, the model does not include investments in new fields or new pipeline capacity but allows for capital development costs associated with incremental output from mature fields. Incremental production is set as a percentage of the total output of the mature field, typically between $10 \%$ and $20 \%$. This percentage is calculated using data from the natural decline of fields when they receive no new capital expenditure. This provides an estimate of incremental output that can be achieved through additional development. All capital costs are discounted for the remaining years of production of the field, applying a depreciation rate of $10 \%$ for the purchase of plant, machinery and equipment in China (EY 2016).

Domestic transportation modes include oil and natural gas pipelines, as well as tanker shipments by rail and truck for crude oil and liquefied natural gas (LNG). Land-based tanker shipments are associated with higher transportation costs when pipelines are unavailable or fully utilized. Oil and gas pipeline, liquefaction and regasification capacities were compiled from an IHS EDIN midstream subscription database (IHS EDIN 2018). We assume unconstrained land-based tanker shipments between adjacent provinces and estimate average transportation costs and other parameters, listed in Table A.2 (Appendix 2).

Finally, we calibrate international prices for oil and gas imports by pipeline and via oceangoing tanker. Average tanker import prices are set to $\$ 306 / \mathrm{mt}$ for oil $(\$ \sim 42 / \mathrm{bbl})$, based on a weighted average of non-pipeline Chinese import prices in 2016 (ITC 2018; World Bank 2018). The same sources were used to calculate an average pipeline import price of $\$ 288 / \mathrm{mt}$ from Central Asia. To address the impact of international crude prices on the economics of China's domestic oil production we run several counterfactual scenarios with a range of import prices, described in detail in the following section.

\section{Scenario Design}

To assess the impact of national policies on China's domestic crude production we first build two scenarios, a baseline scenario to replicate the market conditions in 2016, and a counterfactual open market scenario, also for 2016. Both scenarios 
are short-run, minimizing total supply costs using existing upstream and midstream infrastructure. First, we run the baseline with pipeline contracts from Russia and Central Asia fixed to 2016 levels, and oceangoing tanker imports from the rest of the world, capped at levels reported by the World Trade Organization and the United Nations' International Trade Centre (ITC) (see Table A.2). In the open market scenario, we allow for additional waterborne tanker imports from the international market as a substitute for uneconomic domestic supplies. We only relax tanker imports and keep pipeline contracts fixed to 2016 levels, under the assumption that pipeline imports are less flexible in the short term.

To assess the sensitivity of our simulation to import prices we run additional counterfactual scenarios changing the average crude import price used in the open market scenario of: $\$ 30 / \mathrm{bbl}, \$ 40 / \mathrm{bbl}$, $\$ 50 / \mathrm{bbl}$, $\$ 60 / \mathrm{bbl}, \$ 70 / \mathrm{bbl}, \$ 80 / \mathrm{bbl}$ and $\$ 100 / \mathrm{bbl}$ (or $\$ 221 / \mathrm{mt}$, \$367/mt, \$441/mt, \$515/mt, \$588/mt and $\$ 736 / \mathrm{mt}$ ). In all of these scenarios the natural gas market is calibrated to 2016 market conditions, including price caps on pipeline deliveries to citygate consumers, as presented in Rioux et al. (2018). 


\section{Market Simulation and Analysis}

\section{The open market scenario}

The results from the baseline and open market scenarios are listed in Table 2, including total oil production in million metric tonnes (MMmt), spare capacity (based on domestic oil fields reported to be operational in 2016), import quantities, and costs broken down by production, imports and transportation.

We find that liberalization of crude oil imports, i.e., removing licensing and other indirect constraints limiting buyers' access to imported crude, modeled in the open market scenario, would have significant implications for the domestic Chinese market. Under the conditions observed in 2016, domestic crude oil output would decline by $17.8 \mathrm{MMmt}$, or $8.9 \%$, if these constraints were removed. Under this scenario, domestic production costs decline by $\$ 7.9$ billion, equivalent to $27.1 \%$ of China's overall oil production costs in 2016. These savings are partially offset by increased import costs, providing an overall reduction of $\$ 2.8$ billion, or $1.7 \%$, of total supply costs.

To illustrate how $8.9 \%$ of domestic production can account for $27.1 \%$ of production costs we plot China's domestic supply curve for the baseline and open market scenarios in Figure 2. The last 0.4 million barrels per day MMbbl/d shows a steep incline in China's oil production costs in the baseline scenario. The curve includes operating and capital development costs without transportation costs. Units have been converted to MMbbl/d using the specific gravity of crude reported for each field.

In Figure 3 we show the location of China's domestic production cuts under the open market scenario, by asset ownership and location. It shows how the potential impact of import liberalization varies

Table 2. Key quantity and cost indicators under the modeling scenarios.

\begin{tabular}{|c|c|c|c|}
\hline & Reference & Open market & Difference \\
\hline Production, MMmt & 199.5 & 181.7 & $-8.9 \%$ \\
\hline Spare capacity, MMmt & 0.1 & 17.9 & - \\
\hline Pipeline imports, MMmt & 19.6 & 19.6 & $0 \%$ \\
\hline Tanker imports (sea), MMmt & 361.1 & 379.0 & $5 \%$ \\
\hline Pipeline shipment, billion mt-km & 19.9 & 45.4 & $128.5 \%$ \\
\hline $\begin{array}{l}\text { Tanker shipment (land), billion } \\
\text { mt-km }\end{array}$ & 82.0 & 54.1 & $-34 \%$ \\
\hline Production costs, ( $\$$ billion) & 29.1 & 21.2 & $-27.1 \%$ \\
\hline Import costs, (\$ billion) & 116.3 & 121.7 & $4.7 \%$ \\
\hline Transport costs, ( $\$$ billion) & 0.5 & 0.4 & $-16.4 \%$ \\
\hline Total oil supply costs, (\$ billion) & 145.9 & 143.4 & $-1.7 \%$ \\
\hline Total gas supply costs, (\$ billion) & 24.2 & 23.8 & $-1.4 \%$ \\
\hline Total costs, (\$ billion) & 170.0 & 167.2 & $-1.7 \%$ \\
\hline
\end{tabular}

Source: KAPSARC research. 
Figure 2. Supply curves for domestic production, before transportation, in each scenario.

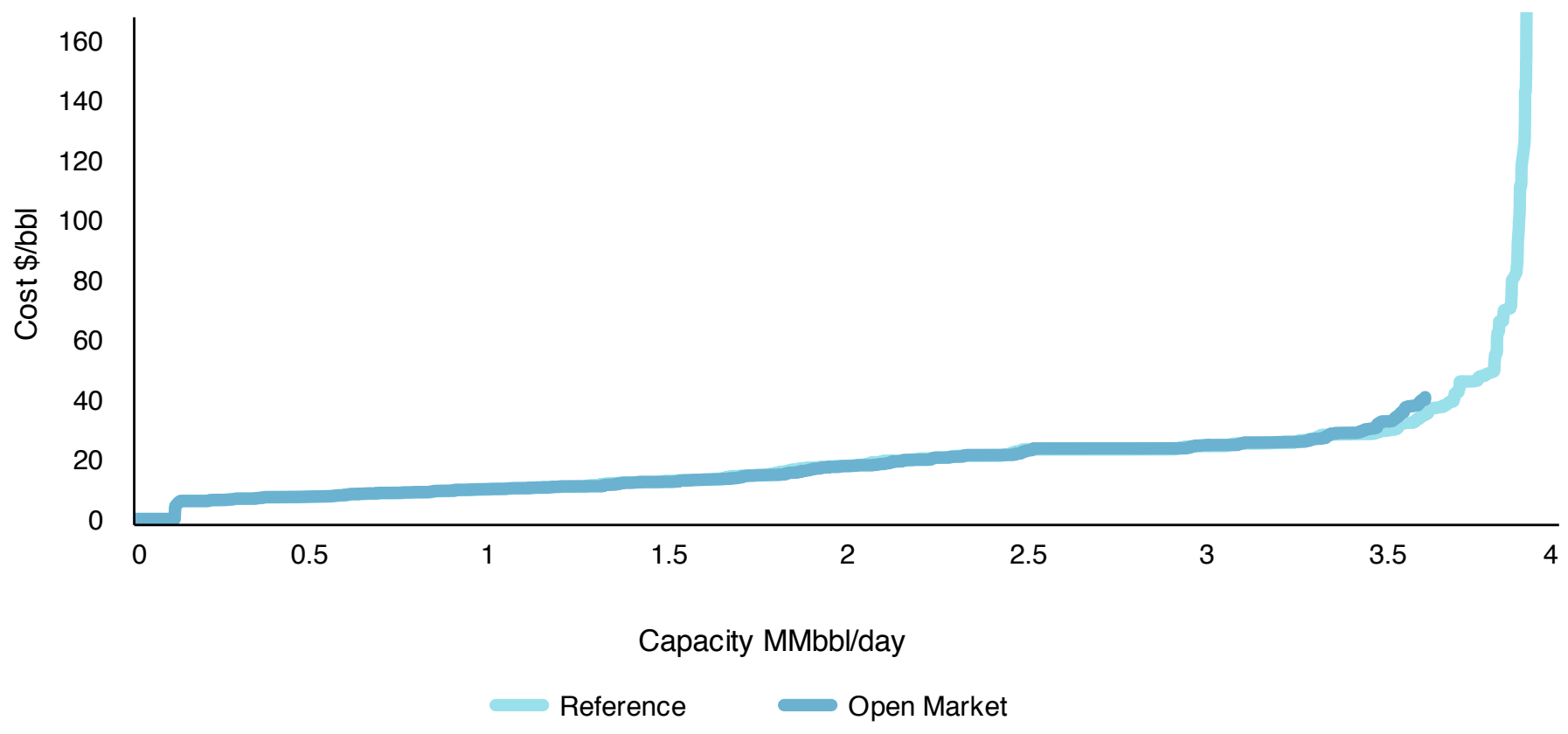

Sources: IHS Vantage, KAPSARC research.

Figure 3. Production decline by operator and region in the open market scenario.

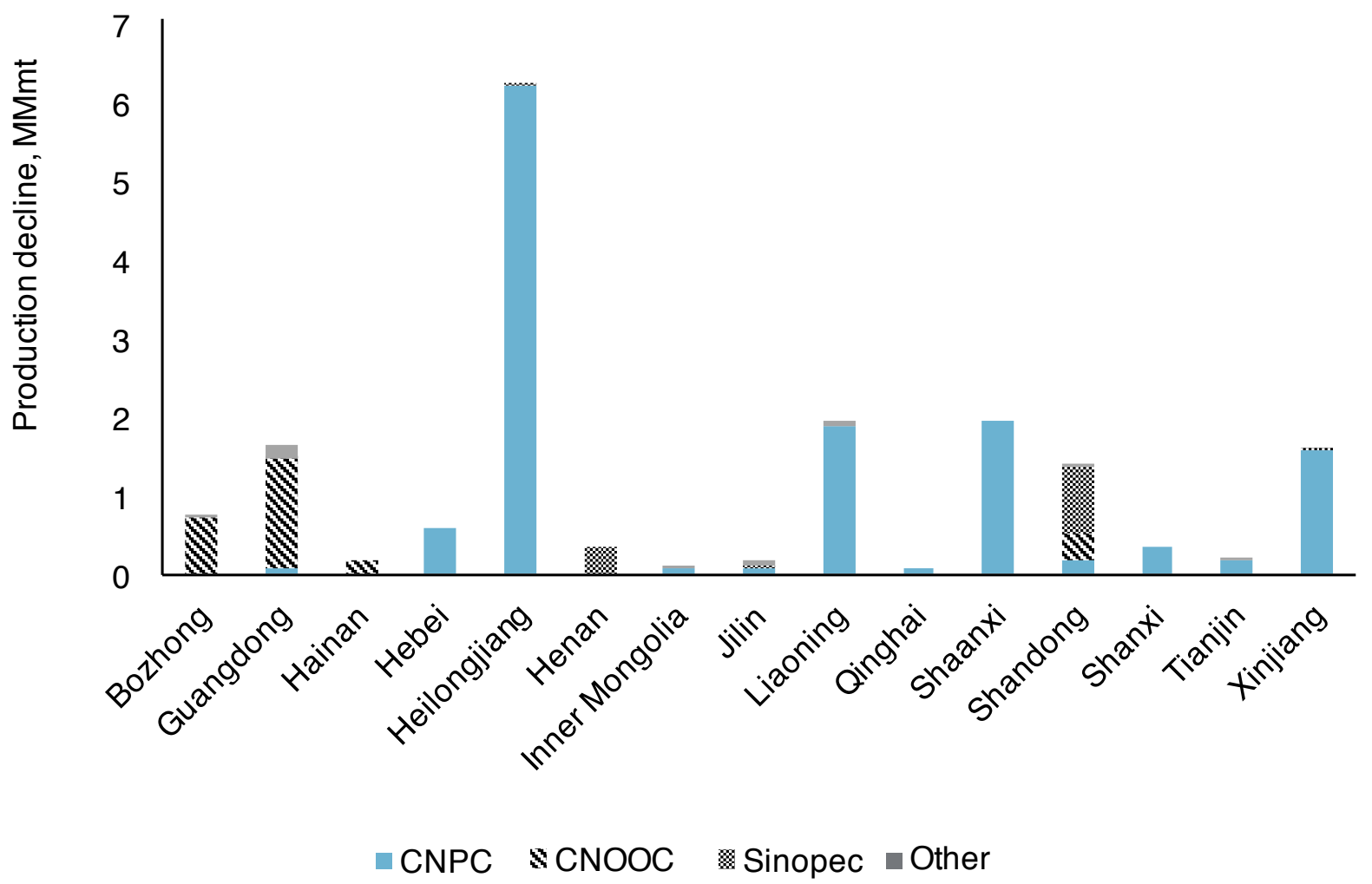

Sources: IHS Vantage, KAPSARC research. 
significantly by region and company. The output declines are found across the country but are primarily concentrated in Northeast China (Heilongjiang and Liaoning provinces) and in the West (Shaanxi and Xinjiang), where crude oil is the most expensive to produce and/or difficult to deliver to consumers. CNPC, China's biggest NOC, has the largest share of decline in production, at about $75 \%$ of the $17.8 \mathrm{MMmt}$. If these declines occurred as a result of government reforms, China's NOCs would be concerned about the potential impact on their supply chains and provincial authorities would have to address the effects of a decline in oil production on regional gross domestic product, tax revenues and employment. Given these factors, the disproportionately large impact of potential reforms at both company and provincial levels might impede the liberalization of the domestic oil market.

The results indicate that certain segments of Chinese domestic oil production are potentially vulnerable to competition from seaborne imports. They can also come under pressure from pipeline imports, which are fixed in our scenarios to existing pipeline contracts. The imported quantities via pipelines from Russia, Kazakhstan and Myanmar in 2016, at 38.9 MMmt, were significantly lower than the nominal combined capacity of these import routes at $30 \mathrm{MMmt}$ (doubled since the second branch of the pipeline from Russia to China opened at the beginning of 2018), $20 \mathrm{MMmt}$ and $22 \mathrm{MMmt}$, respectively (the Myanmar pipeline was completed in 2014 but first crude did not flow through it until May 2017). Moreover, the pipeline import delivery nodes from Russia and Kazakhstan are located in the regions of China with the least economically competitive domestic production assets - the Northeast and far West.

Another factor that somewhat alleviates the impact of a liberalized imports regime, under our baseline scenario, is an improved oil transportation pattern. On the inter-provincial scale, the growth in seaborne tanker imports corresponds to a significant increase in pipeline shipments of more than $100 \%$, at 25.5 billion metric tonne-kilometers (mt-km) (i.e., the product of quantity and distance transported), with an associated decline in less efficient internal land-based tanker shipments of $34 \%$ ( 27.9 billion $\mathrm{mt}-\mathrm{km})$. This suggests that a majority of the production decline occurs in regions with limited access to pipeline infrastructure, where road and rail tanker shipments are needed to deliver oil to consumers. With an increase in seaborne tanker imports under the open market scenario, more oil is directed into existing pipeline networks through well-connected coastal regions. However, if the existing oil pipeline infrastructure cannot be fully and efficiently utilized, due to restrictive pricing mechanisms or inefficient thirdparty access conditions, domestic oil production would be further disadvantaged.

\section{Sensitivity analysis}

Next, we assess the sensitivity of our major indicators of the Chinese oil industry to the crude import price assumption. Table 3 shows the production, spare capacity, seaborne tanker imports, oil supply costs and total supply costs (including natural gas) in the open market scenario under different price assumptions for oil imported through China's coastal provinces.

The amount of spare capacity is sensitive to the import price at or near the initial assumption of around $\$ 42 / \mathrm{bbl}(\$ 306 / \mathrm{mt})$. The spare capacity increases to 25.6 MMmt, or about 0.42 MMbbl/d, when reducing the price to $\$ 30 / \mathrm{bbl}$, while raising the price to $\$ 50 / \mathrm{bbl}$ decreases the spare capacity by about half - to $9 \mathrm{MMmt}$ or about $0.15 \mathrm{MMbbl} / \mathrm{d}$. 
Table 3. Scenario results under different import price assumptions.

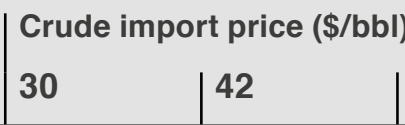

50

60

70

80

100

\begin{tabular}{|c|c|c|c|c|c|c|c|}
\hline \multicolumn{8}{|c|}{ Open market scenario } \\
\hline Production, MMmt & 174.0 & 181.7 & 190.6 & 192.1 & 192.5 & 193.0 & 193.5 \\
\hline Spare capacity, MMmt & 25.6 & 17.9 & 9.0 & 7.5 & 7.1 & 6.6 & 6.1 \\
\hline Tanker imports (sea), MMmt & 402.0 & 379.0 & 370.2 & 368.6 & 368.3 & 367.8 & 367.2 \\
\hline Oil costs, $\$$ billion & 109.8 & 143.4 & 165.6 & 192.5 & 219.7 & 246.7 & 300.4 \\
\hline Total costs, $\$$ billion & 133.9 & 167.2 & 189.5 & 216.4 & 243.5 & 270.6 & 324.3 \\
\hline \multicolumn{8}{|c|}{ Baseline scenario } \\
\hline Total costs, \$ billion & 139.4 & 170.0 & 192.0 & 218.6 & 245.0 & 271.6 & 324.6 \\
\hline Difference, \$ billion & 5.4 & 2.8 & 2.5 & 2.3 & 1.5 & 1.1 & 0.3 \\
\hline
\end{tabular}

Source: KAPSARC research.

Further increases in the import price of crude oil have a smaller impact on domestic production, indicating that even near peak 2018 prices of around $\$ 80 / \mathrm{bbl}$, about 6.6 MMmt (0.11 MMbbl/d) of China's 2016 oil output would be uneconomic, at an additional cost of $\$ 1.1$ billion versus sourcing cheaper imports.

By late 2018, crude prices had fallen back roughly to 2016 levels following sustained increases that started in the second half of 2017 . This can complicate the assessment of how reform initiatives would affect China's domestic oil producers in the short run. However, even at the oil import prices pertaining in late 2018, which were higher than the 2016 average, the short-term impact on domestic producers would likely be less pronounced. This provides a window of opportunity for Chinese policymakers to proceed with further deregulating the country's oil sector and to lift protectionist policies to support the sustainable long-term development of the country's domestic oil industry. 


\section{Conclusions}

O

ur estimations indicate that, despite

significant reforms undertaken since the last

major liberalization of the Chinese economy

in the late 1990s and China's increasing integration into global oil markets, China's domestic oil sector is still negatively affected by the policies that explicitly or implicitly restrict market access to non-stateowned players. The resulting market structure and regulatory environment prioritize production from a number of economically uncompetitive, high-cost mature domestic oil-producing assets. However, this interferes with the regional and national supplydemand equilibrium and impedes the optimal allocation of capital in the upstream oil and fuel transportation sectors, which leads to increased system costs and undermines the long-term competitiveness of the country's oil industry.

Our open market scenario quantifies the effects of these distortions based on market conditions in 2016. We find that removing market access barriers would displace $17.8 \mathrm{MMmt}$, or $8.9 \%$, of inefficient domestic output, primarily located in China's Northeast, with seaborne tanker imports. Together with optimized transportation logistics, this would bring China's oil supply costs down by $\$ 2.8$ billion per year, equivalent to $1.7 \%$ of the country's annual oil supply costs in 2016.

The potential impact of deregulation on local production and imports could be greater still, as the simulations performed in this study are based on the most efficient utilization of existing transport infrastructure. In reality, however, this assumption may be challenged by a lack of market-based pricing mechanisms and restrictions on third-party access to that infrastructure. This would induce refineries, which are primarily located in China's eastern and southern coastal provinces, to further increase their reliance on seaborne crude imports.
The opposite is the case for the country's inland refineries, which have no direct access to ports and pipelines. Higher utilization levels of import terminals and pipeline capacities also pose a threat to less cost-efficient domestic crude oil production.

Our findings suggest that - under current economic conditions - the removal of China's restrictions on purchases of foreign crude would create a significant shift in China's domestic oil supply logistics, as seaborne imports to coastal provinces would increase. This would also have significant implications for the global oil market, as Chinese crude imports could exceed current projections.

On the other hand, the observed sensitivity of uneconomic domestic output to global crude prices implies that, for the price levels reported at the time of writing (December 2018), domestic production would be more competitive than reported in our open market scenario. If 2016 market conditions were replicated under the $\$ 80 / \mathrm{bbl}$ price assumption, deregulation would result in a decrease of only 6.6 MMmt of domestic oil production (or additions to the spare capacity) in China.

Despite trade tensions with the U.S. and renewed Iran sanctions, oil market conditions at the time of writing provide Chinese policymakers with a good opportunity to proceed with more oil sector reforms, without having a significant short-term negative impact on the country's energy security and self-sufficiency targets. In the long run, such measures would likely benefit the country's energy security by helping to establish a more efficient and resilient domestic oil producing sector, and providing a stronger basis for China's international energy integration and governance initiatives.

We have presented a short-term perspective of reforming China's oil industry using a standard 
optimization model. Future research efforts could focus on the long-term effects of reforming China's oil industry, incorporating investments and retirements in the upstream (oil production), as well as in the midstream (pipeline infrastructure). A dynamic modeling framework would require linking with an international oil market outlook and could investigate possible impacts of domestic reforms on the global market. Future efforts might also work toward extending the representation of the midstream sector and the characterization of crude qualities. For example, an initial plan has been proposed to construct a refining sector model for the KAPSARC Energy Model (KEM) of China. Such a tool could be used to investigate connections between refinery stocks, reforms to China's domestic upstream market, and China's demand for crude, differentiated by quality.

The successful implementation of Beijing's proposed oil sector liberalization program is also contingent on the buy-in of key stakeholders. In this regard, potential direct and indirect consequences of the reforms, including short- and long-term impacts on existing supply chains, as well as regional economic, fiscal and employment indicators, should be evaluated not only on the macro and country scale but also at the corporate and provincial levels. 


\section{References}

Bloomberg. 2018. "China Slams Brakes on U.S. Crude Oil Imports." October 5 (updated October 8). https:// www.bloomberg.com/news/articles/2018-10-05/chinaslams-brakes-on-u-s-crude-oil-imports-amid-tradetension

CEIC Data. 2018. China Economic \& Industry Data. Accessed November 15, 2018.

Egging, Ruud, Franziska Holz and Steven A. Gabriel. 2010. "The World Gas Model: A multi-period mixed complementarity model for the global natural gas market." Energy, 10: 4016-4029. https://doi. org/10.1016/j.energy.2010.03.053

Ernst \& Young (EY). 2016. "Worldwide Capital and Fixed Assets Guide." 31-37. https://www.ey.com/Publication/ vwLUAssets/Worldwide_Capital_and_Fixed_Assets_ Guide_2016/\$FILE/Worldwide\%20Capital\%20and\%20 Fixed\%20Assets\%20Guide\%202016.pdf

Gordon, Deborah, Yevgen Sautin and Wang Tao. 2014. "China's Oil Future." Carnegie Endowment for International Peace. May 6. https://carnegieendowment. org/2014/05/06/china-s-oil-future-pub-55437

ICIS. 2015. "China's LNG truck transportation faces oversupply, low crude." Sun Xuelian, April 10, 2015. https://www.icis.com/resources/ news/2015/04/10/9873410/china-s-Ing-trucktransportation-faces-oversupply-low-crude/

IHS Markit EDIN. 2018. "Basin and Midstream Content." Accessed October 23, 2018.

IHS Markit Vantage. 2018. Accessed October 23, 2018.

ITC Trade Map (ITC). 2018. Accessed October 4, 2018. https://www.trademap.org/Index.aspx

Jiao, Jian-ling, Jun-ling Zhang, and Yun-shu Tang. 2010. "A Model for the Optimization of the Petroleum Supply Chain in China and its Empirical Analysis." 2010 International Conference on E-Business and E-Government, Guanghouz, China's, 7-9 May: 3327-3330.

National Development and Reform Commission (NDRC). 2016. The 13th Five-Year Plans for Petroleum and Natural Gas Development. https://policy.

asiapacificenergy.org/sites/default/files/\%E7\%9F\%B3\%
E6\%B2\%B9\%E5\%8F\%91\%E5\%B1\%95\%E2\%80\%9C\% E5\%8D\%81\%E4\%B8\%89\%E4\%BA\%94\%E2\%80\%9D\% E8\%AE\%A1\%E5\%88\%92.pdf

National Energy Administration (NEA). The 13th FiveYear Plan for Energy Development. http://www.ndrc.gov. cn/zcfb/zcfbghwb/201701/W020170117350627940556. pdf

NERA Economic Consulting, 2012. "Macroeconomic Impacts of LNG Exports from the United States." https:// www.energy.gov/sites/prod/files/2013/04/f0/nera_Ing_ report.pdf

Nikkei. 2018. "Shanghai shakes up global oil trading." Asian Review. October 17.https://asia. nikkei.com/Business/Markets/Commodities/ Shanghai-shakes-up-global-oil-trading

Oilprice.com. 2017. "Low Oil Prices Lead to Fastest Mature Fields Decline in 25 Years." July 10. https:// oilprice.com/Energy/Oil-Prices/Low-Oil-Prices-Lead-ToFastest-Mature-Fields-Decline-In-25-Years.html

Qi, Ming and Yumo Yang. 2018. "Towards a sustainable oil supply: a risk diversification model to measure oil security risk in Japan and South Korea." International Journal of Sustainable Development and Planning, 13 (5): 746-757. https://doi.org/10.2495/ SDP-V13-N5-746-757

Reuters. 2017. "China's energy demand to peak in 2040 as transportation demand grows: CNPC." August 16. https://www.reuters.com/article/us-china-cnpcoutlook/chinas-energy-demand-to-peak-in-2040-astransportation-demand-grows-cnpc-idUSKCN1AWODF

Reuters. 2018a. "China's Sinopec Halves Iran oil Loadings under U.S. Pressure." September 28. https:// www.reuters.com/article/us-china-iran-oil/chinassinopec-halves-iran-oil-loadings-under-u-s-pressuresources-idUSKCN1M81D1

Reuters. 2018b. "China's flawed futures contract pushes oil trade to record high in 2018." December 12. https:// www.reuters.com/article/us-crude-oil-futures-chinaanalysis/chinas-flawed-futures-contract-pushes-oiltrade-to-record-high-in-2018-idUSKBN1OB0K7 
Rioux, Bertrand, Philipp Galkin, Frederic Murphy, Axel Pierru, Artem Malov, Felipe Feijoo Palacios, Yan Li and Kang Wu. 2018. "The Economic Impact of Price Controls on China's Natural Gas Supply Chain." KAPSARC Discussion Paper. https://doi.org/10.30573/ ks--2018-dp31

S\&P Global Platts. 2018(a). "CNPC Forecasts Chinese 2018 Oil Demand to Grow 5\% to 12 Million b/d." January 16. https://www.spglobal.com/platts/en/market-insights/ latest-news/oil/011618-cnpc-forecasts-chinese-2018-oildemand-to-grow-5-to-12-million-bd

S\&P Global Platts. 2018(b). "Analysis: China's Slow Strategic Petroleum Reserves Build Signals Reduced Dependency for Energy Security." January 10. https:// www.spglobal.com/platts/en/market-insights/latestnews/oil/011018-analysis-chinas-slow-strategicpetroleum-reserves-build-signals-reduced-dependencyfor-energy-security

Till, Hilary. 2014. "Why Some Futures Contracts Succeed and Others Fail: A Survey of Relevant Research." October 6. EDHEC Business School. https://www.edhec.edu/sites/www.edhec-portail.pprod. net/files/publications/pdf/edhec-working-paper-whysome-futures-contracts_1436277798888-pdfjpg

U.S. Energy Information Administration (EIA). 2018(a). "China Surpassed the United States as the World's Largest Crude Oil Importer in 2017." February 5. https:// www.eia.gov/todayinenergy/detail.php?id=34812
U.S. Energy Information Administration (EIA). 2018(b). "International Energy Statistics." Accessed September 26, 2018. https://www.eia.gov/beta/ international/data/browser/\#/?c=410000000200006 0000000000000g000200000000000000001\&vs=I NTL.44-1-AFRC-QBTU.A\&vo=0\&v=H\&end=2015

Wang, Jianliang, Lianyong Feng, Steve Mohr, Tanga Xu, Tverberg E. Gail and Mikael Höök. 2015. "China's unconventional oil: A review of its resources and outlook for long-term production." Energy, 82: 31-42. https://doi. org/10.1016/j.energy.2014.12.042

World Bank. 2018. World Integrated Trade Solution (WITS). https://wits.worldbank.org/

Xinhua. 2017. "China Unveils Market Reform for Oil and Gas Industry." May 22. http://www.xinhuanet.com// english/2017-05/22/c_136302954.htm

Yang, Zuying, Yuan Zhao, Kelong Huang, and Lisha Hao. 2014. "The spatial optimization of Eastern China's crude oil pipeline network upon cost minimum." Journal of Resources and Ecology 5: 222-227. https://doi. org/10.5814/j.issn.1674-764x.2014.03.004 
Notes

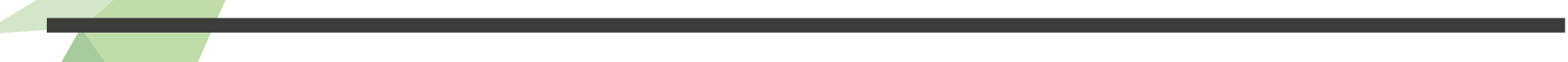




\section{Appendix 1: KAPSARC Energy Model (KEM) of China Oil Model Description}

W e develop an optimization problem, where the suppliers of crude oil coordinate to minimize total supply costs. This problem is an extension of the natural gas module developed for the KAPSARC Energy Model of China (KEM China) by Rioux et al. (2018). A mixed complementarity problem (MCP) approach was used in the original gas module to capture the economic impacts of price caps applied to some segments of China's wholesale natural gas market. Because China's crude oil prices are deregulated, we formulate the supplier's problem as a standard linear program $(L P)$ in equation block (1). The $L P$ is built using the general algebraic modeling system produced by German software company GAMS, and the extended mathematical programming (EMP) framework is used to convert it into the equivalent linear complementarity problem (LCP), and combine it with the MCP formulation of the regulated gas sector. Table A.1 lists all sets, variables and coefficients used in the model.

The variables of the suppliers' problem include the production $q_{i r s}$ by company $i$ in each region $r$ from source $s$ with unique production cost $C P_{i r s}$, the transportation $t_{i j r r^{\prime} w}$ by company $\mathrm{i}$ by pipeline or land

Table A.1. Sets, variables and parameters used in the model.

\begin{tabular}{l|l} 
Sets & \\
\hline \hline$i, j$ & Companies operating in the oil market \\
\hline \hline$r, r^{\prime}$ & Model regions. $r^{*}(r)$ is all import regions, $r^{c}(r)$ only coastal regions with maritime import capacity \\
\hline \hline$s$ & Regional production differentiated by marginal production costs (supply steps) \\
\hline \hline$w$ & Transportation mode \{pipe,tank $\}$ \\
\hline \hline
\end{tabular}

\section{Variables}

\begin{tabular}{l|l}
\hline \hline $\mathrm{d}_{\mathrm{ir}}$ & Crude oil delivered by company $i$ in region $r$ \\
\hline $\mathrm{t}_{\mathrm{ijr} \text { r'w }}$ & Transportation by company i on infrastructure owned by company j from $r$ to $r$ ' by mode w \\
\hline $\mathrm{imp}_{\text {irw }}$ & Quantity of oil imported by company $i$, in region $r$ \\
\hline $\mathrm{q}_{\text {irs }}$ & Natural gas production by company $i$, in $r$, from supply step $s$ \\
\hline
\end{tabular}

\section{Cost coefficients and other parameters}

\begin{tabular}{l|l}
\hline $\mathrm{CL}$ & Aggregate import contract licenses for coastal imports by maritime tanker \\
\hline $\mathrm{CN}_{\mathrm{ir}}$ & Contracts for imported oil purchased by company $i$ in region $r$ for pipeline imports \\
\hline $\mathrm{CP}_{\text {irs }}$ & $\begin{array}{l}\text { Marginal cost of production for company } i \text { in region } r \text { for supply step } s \text {. Includes annualized development costs for } \\
\text { incremental production. }\end{array}$ \\
\hline $\mathrm{CT}_{\text {rr'w }}$ & Variable transportation cost from $r$ to $r^{\prime}$ for gas type w \\
\hline $\mathrm{D}_{\mathrm{r}}$ & Fixed oil demand in region $r$ \\
\hline $\mathrm{E}_{\text {irs }}$ & Production capacity by company $i$, in region $r$, and supply step $s$ \\
\hline $\mathrm{F}_{\text {jrr' }}$ & Transportation capacity owned by company j from region $r$ to $r^{\prime}$ for pipelines \\
\hline $\mathrm{I}_{\mathrm{rw}}$ & Import price in region $r$ by mode $w$ \\
\hline $\mathrm{Y}_{\mathrm{rr} \text { 'w }}$ & Transportation yield by mode $w$ \\
\hline \hline
\end{tabular}


based tanker ( $w$ ) owned by company $j$ connecting regions $r$ to $r^{\prime}$, imports $i m p_{i r w}$ and final delivery $d_{i r}$ to each region by each corporation. The suppliers' objective function (1) is to minimize the aggregate costs of all companies, including the marginal cost of production $\sum_{i r s} C P_{i r s} q_{i r s}$, the cost of transportation $\sum_{i j r^{\prime} w} C T_{r r^{\prime} w} t_{i j r r^{\prime} w}$, and imports $\sum_{i r w} l_{r w} i m p_{i r w}$ subject to constraints (1.1) to (1.6).

The companies must meet a fixed demand for crude $D_{r}$ in (1.1), with each unit of production bound by the available capacity $E_{i r s}$ in (1.2). Constraint (1.3) describes the supply balance between model regions, where for each company i the total production plus imports (from available regions $r^{*}$ ) and transportation (times the transportation yield $Y_{r r^{\prime} w_{w}}$ ) into region $r$ must be greater than the transportation, leaving $r$ plus the final distribution by each company. The transportation constraint for inter-regional pipeline capacity $F_{j r r}$ owned by company $j$ is defined in (1.4), while existing pipeline import contracts $\mathrm{CN}_{\text {irw }}$ are set as a lower bound in (1.5). The final constraint (1.6) sets the maximum amount of aggregate seaborne tanker imports from coastal regions $r^{c}$ as $C L$. The coefficient represents policies implemented by the Chinese government to protect domestic producers.

$\min z=\sum_{i r s} C P_{i r s} q_{i r s}+\sum_{i j r r \prime w} C T_{r r / w} t_{i j r r \prime w}+\sum_{i r w} I_{r w} i m p_{i r w}$

s.t.

$\sum_{i} d_{i r} \geq D_{r}$

$\forall i r$

$q_{\text {irs }} \leq E_{\text {irs }}$

$\forall$ irs

$\sum_{s} q_{i r s}+\sum_{w}$

$+d_{i r} \forall i r$

$\sum_{i} t_{i j r r^{\prime} w} \leq F_{j r r}$

$\forall i r r^{\prime}, w=$ pipe

$i m p_{\text {irw }} \geq C N_{\text {irw }}$

$\forall r^{*}(r), w=$ pipe

$\sum_{i r^{c}(r)} i m p_{i r w} \leq C L$

$\forall w=\tan k$

$d_{\text {ir }} \geq 0, q_{\text {irs }} \geq 0, i m p_{\text {irw }} \geq 0, t_{i j r r^{\prime} w} \geq 0$ 


\section{Appendix 2: Model Calibration}

Table A.2. Variable costs, yields and other model calibration coefficients.

\begin{tabular}{l|l|l} 
Natural gas parameters & Value* & Reference \\
\cline { 1 - 2 } Pipeline transport cost & $\$ 0.00210 / \mathrm{Mcm}-\mathrm{km}$ & Rioux et al. 2018 \\
\hline Pipeline losses & $0.002 \% / \mathrm{km}$ & ICIS 2015 \\
\hline LNG transportation (truck) & $\$ 0.0118 / \mathrm{Mcm}-\mathrm{km}$ & Nera 2012 (Southeast Asia) \\
\hline Regasification cost & $\$ 12 / \mathrm{Mcm}$ & Egging et al. 2010 \\
\hline Regasification yield & $98.6 \%$ & Nera 2012 (Southeast Asia) \\
\hline Liquefaction cost & $\$ 10 / \mathrm{Mcm}$ & Egging et al. 2010 \\
\hline Liquefaction yield & $88 \%$ & \\
\cline { 1 - 1 } Pipeline imports in 2016 & $38.9 \mathrm{bcm}$ & \multirow{2}{*}{ ITC 2018, KAPSARC analysis } \\
\cline { 1 - 2 } Tanker seaborne imports in 2016 & $36.2 \mathrm{bcm}$ &
\end{tabular}

\begin{tabular}{|c|c|c|}
\hline Crude oil parameters & Value & Reference \\
\hline Pipeline transport costs & $\$ 0.0025 / \mathrm{mt}-\mathrm{km}$ & \multirow{2}{*}{ KAPSARC analysis } \\
\hline Tanker transportation costs (rail) & $\$ 0.0050 / \mathrm{mt}-\mathrm{km}$ & \\
\hline Pipeline imports in 2016 & $20.5 \mathrm{MMmt}$ & \multirow{4}{*}{ ITC 2018, KAPSARC analysis } \\
\hline Tanker seaborne imports in 2016 & 360.4 MMmt & \\
\hline $\begin{array}{l}\text { Pipeline import price (Central Asian } \\
\text { imports) }\end{array}$ & $\$ 288 / M M m t$ & \\
\hline Tankerseaborne import price & $\$ 306 / \mathrm{mt}$ & \\
\hline
\end{tabular}

* Natural gas units are thousand cubic meters (Mcm), thousand cubic meter kilometers (Mcm-km), and billion cubic meters (bcm). Oil units are metric tonnes (mt), metric tonne-kilometers (mt-km) and million metric tonnes (MMmt).

Source: KAPSARC research. 


\section{About the Authors}

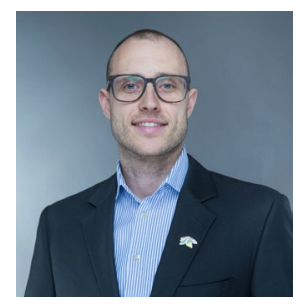

\section{Bertrand Rioux}

Bertrand is a research fellow developing energy systems models. He completed a master's thesis in computational fluid dynamics at the King Abdullah University of Science and Technology (KAUST) Thuwal, Saudi Arabia..

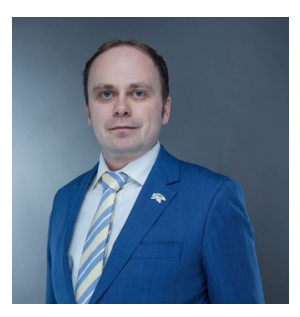

\section{Philipp Galkin}

Philipp is a visiting research fellow specializing in the economic and policy aspects of energy supply and trade. He holds a Ph.D. in International Economic Relations and an MBA.

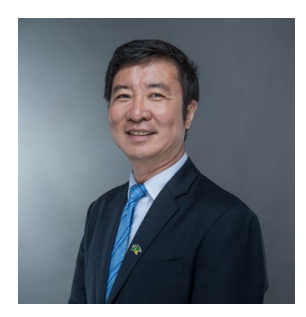

\section{Kang Wu}

Kang was a program director for Markets and Industrial Development at KAPSARC and is currently Head of Analytics, Asia, at S\&P Global Platts, Singpore. He holds a Ph.D. in Economics and has many years of energy research and consulting experience, focusing on Asia.

\section{About the Project}

The KAPSARC Energy Model of China (KEM China) project began in 2014 to study energy and environmental issues in China. KEM China has been developed to understand China's energy economy and fuel mix and how they are impacted by government intervention, as well as by their interaction with global markets. KEM China is a modular integrated mixed complementarity problem model that optimizes supply decisions, minimizing fuel and technology costs, while taking into account the effect of government regulation on prices and the environment. 
INAPSARC

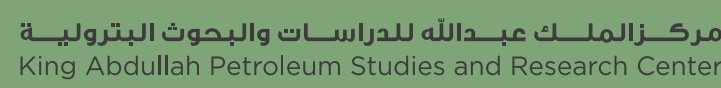

www.kapsarc.org 